\title{
Weekly nab-Paclitaxel in Metastatic Breast Cancer - Summary and Results of an Expert Panel Discussion
}

\author{
Christian Jackisch $^{\mathrm{a}}$ Hans-Joachim Lück ${ }^{\mathrm{b}}$ Michael Untch ${ }^{\mathrm{c}}$ Joachim Bischoff ${ }^{\mathrm{d}}$ \\ Volkmar Müller ${ }^{\mathrm{e}}$ Marcus Schmidt ${ }^{\dagger}$ Marc Thillg Marion Kiechle $^{\mathrm{h}}$
}

aKlinik für Gynäkologie und Geburtshilfe, Klinikum Offenbach, 'bynäkologisch-Onkologische Schwerpunktpraxis, Hannover, 'Klinik für Gynäkologie, HELIOS Klinikum Berlin-Buch, dUniversitätsfrauenklinik, Universitätsklinikum Magdeburg,

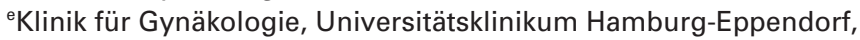

${ }^{f}$ Klinik und Poliklinik für Geburtshilfe und Frauenkrankheiten, Universitätsmedizin der Universität Mainz,

${ }^{9}$ Klinik für Frauenheilkunde und Geburtshilfe, Universitätsklinikum Schleswig-Holstein, Campus Lübeck,

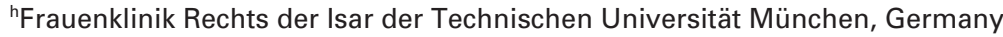

\section{Keywords}

First-line therapy - Metastatic breast cancer . Chemotherapy · Weekly · nab-Paclitaxel .

Paclitaxel · Docetaxel

\section{Summary}

Taxanes are regarded as the most effective single agents in the treatment of metastatic breast cancer (MBC). For conventional taxanes, crucial toxicities and impairments in clinical efficacy are related to solvents necessary because of the agents' hydrophobicity. The mandatory premedication with corticosteroids causes additional side effects. Nab-paclitaxel is a solvent-free colloidal suspension of paclitaxel and human serum albumin that exploits the physiological transport properties of albumin. It is registered as monotherapy with a recommended dose of $260 \mathrm{mg} / \mathrm{m}^{2}$ every 3 weeks for the treatment of patients with MBC, who have failed a first-line treatment of metastatic disease and for whom a standard anthracycline treatment is not indicated. Clinical evidence is available for the registered 3-weekly administration and for alternative weekly schedules in first and further lines of therapy of patients with MBC. During an advisory board meeting, a group of 8 German breast cancer experts reviewed the clinical data of nab-paclitaxel in MBC and discussed how nab-paclitaxel could be used in clinical practice on the basis of the current data.

\author{
Schlüsselwörter \\ Erstlinientherapie - Metastasiertes Mammakarzinom . \\ Chemotherapie · Wöchentlich · nab-Paclitaxel . \\ Paclitaxel · Docetaxel
}

\section{Zusammenfassung}

Taxane gelten als die wirksamsten Substanzen in der Therapie des metastasierten Mammakarzinoms. Relevante Nebenwirkungen der konventionellen Taxane und Einschränkungen ihrer klinischen Wirksamkeit werden wesentlich durch die aufgrund ihrer hydrophoben Eigenschaften notwendigen Lösungsmittel verursacht. Die obligate Prämedikation mit Kortikosteroiden bedingt weitere Nebenwirkungen. Nab-Paclitaxel ist eine lösungsmittelfreie, kolloidale Suspension von Paclitaxel und humanem Serumalbumin. Es nutzt die natürlichen Transporteigenschaften von Albumin. Nab-Paclitaxel ist als Monotherapie mit einer empfohlenen Dosierung von $260 \mathrm{mg} / \mathrm{m}^{2}$ alle 3 Wochen für die Behandlung des metastasierten Mammakarzinoms bei erwachsenen Patientinnen zugelassen, bei denen die Erstlinientherapie der metastasierten Erkrankung fehlgeschlagen ist und für die eine standardmäßige Anthrazyklin-enthaltende Therapie nicht angezeigt ist. Daten aus klinischen Studien liegen für das zugelassene 3-wöchentliche Schema und für alternative wöchentliche Dosierungen in der Erstlinienund Mehrlinientherapie von Patientinnen mit metastasiertem Mammakarzinom vor. Eine Gruppe von 8 deutschen Brustkrebsexperten begutachtete und diskutierte im Rahmen eines Advisory Boards die klinischen Daten zu nab-Paclitaxel in der Therapie des metastasierten Mammakarzinoms und diskutierte wie nab-Paclitaxel in der klinischen Praxis auf Grund der aktuellen Daten optimal eingesetzt werden sollte.

\section{KARGER \\ Fax +497614520714 \\ Information@Karger.de}

www.karger.com (c) 2012 S. Karger GmbH, Freiburg

661-3791/12/0072-0137\$38.00/0

Accessible online at:

www.karger.com/brc 


\section{Introduction}

There is growing evidence from clinical trials suggesting that the use of chemotherapy is improving survival even in metastatic breast cancer (MBC). Retrospective analyses of clinical trials have shown chemotherapy to result in prolongation of median overall survival of patients with MBC over time. The current guidelines of the German AGO (Arbeitsgemeinschaft für Gynäkologische Onkologie; Working Group on Breast Cancer) breast group recommend chemotherapy with a single cytotoxic agent if patients progress slowly and do not suffer from considerable symptoms or life-threatening disease, and restrict polychemotherapy to the treatment of patients with considerable symptoms and acute life-threatening metastases [1]. The choice of cytotoxic agent to be used depends on the aggressiveness of the disease and the site of metastasis, tumor biology, combination with biologicals, prior exposure to other cytotoxic agents, patient's age and performance status, and last but not least the patient's expectations and reservations especially regarding specific toxicities.

Taxanes are regarded as the most effective single agents in the treatment of breast cancer and as the agents of choice in anthracycline-pretreated patients according to the most recent AGO guidelines [1]. Docetaxel and paclitaxel have been registered as 3-weekly regimens. However, for paclitaxel weekly administration is regarded as the gold standard based on clinical evidence in adjuvant [2] and metastatic disease [3]. Despite their clinical activity, the use of conventional taxanes is often limited by significant toxicities that remain a major challenge especially when treating patients with MBC. Crucial toxicities and impairments in clinical efficacy are based on solvents necessary because of the agents' hydrophobicity. Cremophor used as solvent in paclitaxel has been reported to be associated with several major side effects such as neutropenia, hypersensitivity reactions, and neuropathy due to axonal degeneration [4]. Polysorbat 80, the solvent used in docetaxel, has been shown to partially contribute to fluid retention by altering membrane fluidity [5]. Thus, the dose of paclitaxel and docetaxel that can be administered is limited by these toxic effects. Formation of large polar micelles of cremophordissolved paclitaxel in the plasma compartment and subsequent entrapment of the drug leads to non-linear pharmacokinetics $[6,7]$. Also, docetaxel and paclitaxel are now broadly used in adjuvant chemotherapy regimens. Thus, the majority of patients will have been exposed to either of these 2 taxanes once they develop metastases. For palliative chemotherapy of patients with $\mathrm{MBC}$ pretreated with taxanes and anthracyclines, the current AGO guidelines clearly recommend the inclusion into clinical trials (AGO evidence-based recommendations on therapy of primary and advanced breast cancer, grade of recommendation ++ ) or monotherapy with capecitabine (AGO evidence-based recommendations on therapy of primary and advanced breast cancer, grade of recommendation ++ ). Monotherapy with pegylated liposomal doxorubicin or with single agent vinorelbine are 2 further options with a weaker grade of recommendation (AGO evidence-based recommendations on therapy of primary and advanced breast cancer, grade of recommendation + ) [1]

$N a b$-paclitaxel is a solvent-free colloidal suspension of paclitaxel and human serum albumin that exploits the physiological transport properties of albumin. The nanoparticle drug delivery system eliminates the need for toxic solvents like cremophor through binding of paclitaxel to albumin, thus alleviating the limitations of paclitaxel dosing and affecting overall drug efficacy. Moreover, albumin binding to the glycoprotein receptor gp60 on endothelial cells results in activation of caveolin-1 and the transcytosis of intact nanoparticles across the cell membrane [8], and thus facilitates the passage of paclitaxel from the bloodstream via the blood vessels to the underlying tumor tissue. Nab-paclitaxel has shown good clinical results in first- and further line therapy of patients with MBC [9-11]. It has also demonstrated considerable activity in taxane-pretreated patients with $\mathrm{MBC}$ [12]. It is registered as monotherapy with a recommended dose of $260 \mathrm{mg} / \mathrm{m}^{2}$ every 3 weeks ( $\mathrm{q} 3 \mathrm{w}$ ) for the treatment of patients with MBC, who have failed a first-line treatment of metastatic disease and for whom a standard anthracycline treatment is not indicated [13]. Clinical evidence is available for the registered 3-weekly administration and for alternative weekly schedules. This paper summarizes the data and the authors' view of how nabpaclitaxel could be used in the treatment of patients with $\mathrm{MBC}$ in clinical practice based on the review and discussion of available data at a 1-day advisory board meeting.

\section{Overview of Clinical Trials with nab-Paclitaxel in MBC}

\section{Pivotal Phase III Study: nab-Paclitaxel versus Conventional Paclitaxel}

In the pivotal phase III trial in MBC [9], 460 patients randomly received $n a b$-paclitaxel dosed at $260 \mathrm{mg} / \mathrm{m}^{2}$ (no premedication, 30-min infusion) or solvent-based paclitaxel dosed at $175 \mathrm{mg} / \mathrm{m}^{2}$ (standard premedication with antihistamines and dexamethasone) on day $1 \mathrm{q} 3 \mathrm{w}$. Roughly $40 \%$ were first-line patients, and around $80 \%$ of patients had been pretreated with anthracyclines. Intention-to-treat (ITT) analyses demonstrated for all patients that the overall response rate for $n a b$-paclitaxel was significantly greater than for standard paclitaxel (33 vs. 19\%; $\mathrm{p}=0.001$ ). This was confirmed for patients who received first-line therapy (42 vs. $27 \%$; $p=0.029$ ), patients who received second-line or greater therapy (27 vs. $13 \% ; \mathrm{p}=0.006)$, and patients who had received prior anthracycline therapy in the adjuvant or metastatic setting (34 vs. $18 \% ; p=0.002)$ or the metastatic setting only (27 vs. $14 \%$; $\mathrm{p}=0.01)$ and further subgroups. Median time to progression was significantly longer with $n a b$-paclitaxel than with standard paclitaxel for all patients (23.0 vs. 16.9 weeks, hazard ratio $(\mathrm{HR})=0.75 ; \mathrm{p}=0.006)$ and for patients who received second- 
or further line therapy (20.9 vs. 16.1 weeks, HR =0.73; $\mathrm{p}=0.02$ ). Median overall survival for treatment with $n a b$ paclitaxel was absolutely greater than for conventional paclitaxel (65.0 vs. 55.7 weeks) without reaching statistical significance, but was significantly prolonged by $n a b$-paclitaxel in second- and further line treatment (56.4 vs. 46.7 weeks, HR = $0.73 ; \mathrm{p}=0.024)$. Patients treated with $n a b$-paclitaxel received an on average $49 \%$ greater dose intensity. There were no differences in quality of life between the 2 treatment groups. $N a b$-paclitaxel was well tolerated with a significantly lower rate of neutropenia as compared to standard paclitaxel. Grade 3 sensory neuropathy was higher for $n a b$-paclitaxel as compared to standard paclitaxel (10 vs. $2 \%$ ), but this could be managed easily with dose reductions and interruptions and improved more rapidly as compared to neuropathy under conventional paclitaxel (median 22 vs. 79 days, respectively). No episodes of motor neuropathy or grade 4 sensory neuropathy were reported.

\section{Weekly Administration of nab-Paclitaxel as Single Agent in $M B C$}

In a randomized phase II study, 302 first-line patients randomly received either $n a b$-paclitaxel at a dose of $300 \mathrm{mg} / \mathrm{m}^{2}$ on day $1 \mathrm{q} 3 \mathrm{w}, 100 \mathrm{mg} / \mathrm{m}^{2}$ or $150 \mathrm{mg} / \mathrm{m}^{2}$ on days $1 / 8 / 15 \mathrm{q} 1 \mathrm{w}$ or docetaxel at a dose of $100 \mathrm{mg} / \mathrm{m}^{2}$ on day $1 \mathrm{q} 3 \mathrm{w}$ [10]. $\mathrm{Nab}$ paclitaxel at $100 / 150 \mathrm{mg} / \mathrm{m}^{2}$ weekly showed a higher overall response rate than docetaxel (45/49\% vs. $35 \%$, respectively) as assessed by an independent radiologist review, but this did not reach statistical significance. On the basis of investigator assessment, there was a significant increase in overall response rate for $n a b$-paclitaxel at $100 \mathrm{mg} / \mathrm{m}^{2}(\mathrm{p}<0.001)$ and $150 \mathrm{mg} / \mathrm{m}^{2}$ ( $\left.\mathrm{p}=0.002\right)$ versus docetaxel (63 and $74 \%$ vs. $39 \%$, respectively). Furthermore, the independent radiologist assessed the independent disease control rate to be significantly higher for $n a b$-paclitaxel at both $100 \mathrm{mg} / \mathrm{m}^{2}(\mathrm{p}=0.009)$ and $150 \mathrm{mg} / \mathrm{m}^{2}(\mathrm{p}=0.017)$ versus docetaxel $(75$ and $80 \%$ vs. $58 \%$, respectively).

Treatment with $n a b$-paclitaxel $150 \mathrm{mg} / \mathrm{m}^{2}$ weekly resulted in significantly longer median progression-free survival as compared to docetaxel in both the independent radiologist assessment (12.9 vs. 7.5 months, HR 0.495; $p=0.0065)$ and the investigator (14.6 vs. 7.8 months, HR $0.568 ; \mathrm{p}=0.012$ ) assessment. No statistical difference between $300 \mathrm{mg} / \mathrm{m}^{2}$ nab-paclitaxel $\mathrm{q} 3 \mathrm{w}$ and docetaxel treatment was observed in terms of overall response rate, disease control rate, and progressionfree survival.

When results were reported by Gradishar et al. in 2009 [10], survival data were not yet mature. A final analysis of survival was presented very recently at the 2011 ASCO Breast Cancer Symposium [11]. Nab-paclitaxel at $150 \mathrm{mg} / \mathrm{m}^{2}$ weekly showed a median overall survival of 33.8 months as compared to 22.2 months for $n a b$-paclitaxel $100 \mathrm{mg} / \mathrm{m}^{2}$ weekly, 27.7 months for $n a b$-paclitaxel $300 \mathrm{mg} / \mathrm{m}^{2} \mathrm{q} 3 \mathrm{w}$, and 26.6 months for docetaxel $100 \mathrm{mg} / \mathrm{m}^{2} \mathrm{q} 3 \mathrm{w}$. However, statistical significance was only reached for the comparison of $n a b$-paclitaxel $150 \mathrm{mg} / \mathrm{m}^{2}$ vs. $n a b$-paclitaxel $100 \mathrm{mg} / \mathrm{m}^{2}$ ( $\left.\mathrm{p}=0.008\right)$. For docetaxel, a higher rate of grade $3 / 4$ fatigue, neutropenia, and febrile neutropenia was reported. The incidence of sensory neuropathy was similar in the docetaxel regimen and all 3 nab-paclitaxel regimens ( $p>0.1$ for all 3 comparisons). The median time to onset of grade 3 neuropathy was 151 $\left(300 \mathrm{mg} / \mathrm{m}^{2}\right), 189\left(100 \mathrm{mg} / \mathrm{m}^{2}\right)$, and $162\left(150 \mathrm{mg} / \mathrm{m}^{2}\right)$ days for $n a b$-paclitaxel, and 176 days for docetaxel. Median time to improvement to $\leq$ grade 2 was shorter for all $n a b$-paclitaxel arms with a minimum of 20 days (median) for the $150 \mathrm{mg} / \mathrm{m}^{2}$ weekly schedule, as compared to 41 days (median) for docetaxel [11].

Safety results were also reported for an ongoing phase II study of $n a b$-paclitaxel at $100 \mathrm{mg} / \mathrm{m}^{2}$ as first-line therapy in 23 patients with and 58 without prior adjuvant or neoadjuvant taxane exposure. Treatment was well tolerated. Neuropathy grade $1 / 2$ occurred in $17 \%$ of patients. There was no grade $3 / 4$ sensory neuropathy [14].

Another phase II study included patients with MBC, whose disease progressed despite conventional taxane therapy. Taxane failure was defined as metastatic disease progression during taxane therapy or relapse within 12 months of adjuvant taxane therapy. Patients with a median of 3 prior chemotherapies (range 0-14) including paclitaxel, docetaxel, or both were treated with $n a b$-paclitaxel at $100 \mathrm{mg} / \mathrm{m}^{2}(\mathrm{n}=106)$ and in a second cohort at $125 \mathrm{mg} / \mathrm{m}^{2}(\mathrm{n}=75)$ on days $1 / 8 / 15 \mathrm{q} 4 \mathrm{w}$ [12]. Overall response rate was 14 and $16 \%$, disease control rate 26 and $37 \%$, median progression-free survival 3 and 3.5 months, and median overall survival 9.2 and 9.1 months, respectively. No survival difference was observed between patients who achieved stable disease $\geq 16$ weeks and those with a confirmed response. Patients received a median of 15.2 doses in the $100 \mathrm{mg} / \mathrm{m}^{2}$ cohort and of 13.1 doses in the $125 \mathrm{mg} / \mathrm{m}^{2}$ cohort corresponding to median cumulative doses of 900.5 and 1,125 $\mathrm{mg} / \mathrm{m}^{2}$, respectively. $\mathrm{Nab}$-paclitaxel was generally well tolerated. $9(8 \%)$ patients in the $100 \mathrm{mg} / \mathrm{m}^{2}$ cohort and $14(19 \%)$ in the $125 \mathrm{mg} / \mathrm{m}^{2}$ cohort developed grade 3 sensory neuropathy. In both groups, 3 patients had preexisting grade 1 neuropathy. Median onset occurred after 5 and 3 cycles, respectively. No grade 4 sensory neuropathy was reported. Patients who developed treatment-limiting peripheral neuropathy could be restarted on a reduced dose of $n a b$-paclitaxel after a delay of 1-2 weeks. A short overview of the trials with weekly single agent $n a b$-paclitaxel in MBC described in detail above is given in table 1.

\section{Weekly nab-Paclitaxel in Combination with Other Cytotoxic and/or Biological Agents}

In a phase II trial, 50 patients received first-line treatment with $n a b$-paclitaxel at $125 \mathrm{mg} / \mathrm{m}^{2}$ with no premedication on days $1 / 8$ and capecitabine $825 \mathrm{mg} / \mathrm{m}^{2}$ twice a day on days 1-14 of a 21-day cycle. In 38 patients evaluable for response, overall response was $47.5 \%$ and the disease control rate $87 \%$. 
Table 1. Overview of weekly single agent $n a b$-paclitaxel schedules in metastatic breast cancer

\begin{tabular}{|c|c|c|c|c|c|}
\hline Study [ref.] & $\mathrm{n}$ & Treatment line & $n a b$-Paclitaxel & Efficacy & Toxicity \\
\hline Gradishar et al. $[10,11]$ & 74 & first-line & $\begin{array}{l}150 \mathrm{mg} / \mathrm{m}^{2} \\
\text { days } 1 / 8 / 15 \mathrm{q} 28 \mathrm{~d}\end{array}$ & $\begin{array}{l}\text { ORR } 49 \%, \text { DCR } 80 \%, \text { PFS } \\
12.9 \text { months, OS } 33.8 \text { months }\end{array}$ & $\begin{array}{l}44 \% \text { grade } 3 / 4 \text { neutropenia, } \\
14 \% \text { grade } 3 \text { sensory } \\
\text { neuropathy }\end{array}$ \\
\hline Gradishar et al. [10, 11] & 76 & first-line & $\begin{array}{l}100 \mathrm{mg} / \mathrm{m}^{2} \\
\text { days } 1 / 8 / 15 \mathrm{q} 28 \mathrm{~d}\end{array}$ & $\begin{array}{l}\text { ORR } 45 \% \text {, DCR } 75 \% \text {, PFS } \\
12.8 \text { months, OS } 22.2 \text { months }\end{array}$ & $\begin{array}{l}25 \% \text { grade } 3 / 4 \text { neutropenia, } \\
8 \% \text { grade } 3 \text { sensory neuropathy }\end{array}$ \\
\hline Brezden et al. [14] & 81 & first-line & $100 \mathrm{mg} / \mathrm{m}^{2}$ weekly & not reported & $\begin{array}{l}9 \% \text { grade } 3 / 4 \text { neutropenia, } \\
\text { no grade } 3 \text { or } 4 \text { neuropathy }\end{array}$ \\
\hline Mirtsching et al. [21] & 50 & first-line & $\begin{array}{l}125 \mathrm{mg} / \mathrm{m}^{2} \\
\text { days } 1 / 8 / 15 \mathrm{q} 28 \mathrm{~d}\end{array}$ & $\begin{array}{l}\text { ORR } 38.1 \% \text {, PFS } 12.8 \text { months, } \\
\text { OS } 27.3 \text { months }\end{array}$ & $\begin{array}{l}11 \% \text { grade } 3 \text { neutropenia, } \\
8 \% \text { grade } 3 \text { sensory neuropathy }\end{array}$ \\
\hline Blum et al. [12] & 75 & $\begin{array}{l}\text { median of } 3 \text { prior lines, } \\
\text { taxane-refractory }\end{array}$ & $\begin{array}{l}125 \mathrm{mg} / \mathrm{m}^{2} \\
\text { days } 1 / 8 / 15 \mathrm{q} 28 \mathrm{~d}\end{array}$ & $\begin{array}{l}\text { ORR } 16 \% \text {, PFS } 3.5 \text { months, } \\
\text { OS } 9.1 \text { months }\end{array}$ & $\begin{array}{l}34 \% \text { grade } 3 / 4 \text { neutropenia, } \\
19 \% \text { grade } 3 \text { sensory } \\
\text { neuropathy }\end{array}$ \\
\hline Blum et al. [12] & 106 & $\begin{array}{l}\text { median of } 3 \text { prior lines, } \\
\text { taxane-refractory }\end{array}$ & $\begin{array}{l}100 \mathrm{mg} / \mathrm{m}^{2} \\
\text { days } 1 / 8 / 15 \mathrm{q} 28 \mathrm{~d}\end{array}$ & $\begin{array}{l}\text { ORR } 14 \% \text {, PFS } 3 \text { months, } \\
\text { OS } 9.2 \text { months }\end{array}$ & $\begin{array}{l}18 \% \text { grade } 3 / 4 \text { neutropenia, } \\
8 \% \text { grade } 3 \text { sensory neuropathy }\end{array}$ \\
\hline
\end{tabular}

Grade $3 / 4$ non-hematological toxicity occurred in $23.3 \%$ of patients. The incidence of grade $1 / 2$ neuropathy was $25 \%$, and there was no grade $3 / 4$ neurotoxicity [15].

First-line combination therapy of weekly $n a b$-paclitaxel and gemcitabine was evaluated in a phase II trial enrolling 50 patients. Nab-paclitaxel was administered at $125 \mathrm{mg} / \mathrm{m}^{2}$ and gemcitabine at $1,000 \mathrm{mg} / \mathrm{m}^{2}$ on days $1 / 8$ every 21 days. Overall response rate by RECIST was $50 \%$, median progression-free survival 7.9 months, and overall survival at 6 months $92 \%$. The most common toxicity was neutropenia with $42 \%$ grade 3 and $12 \%$ grade 4 . Neutropenia was generally uncomplicated and managed in an outpatient setting. There was only 1 episode of febrile neutropenia. Neuropathy grade 3 occurred in $8 \%$ of patients [16].

A phase II study by the US Oncology Research Network enrolled patients with HER2-negative MBC to receive firstline therapy with $n a b$-paclitaxel $125 \mathrm{mg} / \mathrm{m}^{2}$ on days $1 / 8 / 15$ and bevacizumab $10 \mathrm{mg} / \mathrm{kg}$ on days $1 / 15$ of a 28 -day cycle. Patients had received prior anthracyclines (41\%), docetaxel (12\%), and paclitaxel $(12 \%)$ as part of their adjuvant treatment. The confirmed overall response rate was $30 \%$ and the disease control rate $52 \%$ for the 45 patients evaluable for response. The median progression-free survival was 9.4 months. $46 \%$ of patients experienced $>$ grade 3 neutropenia, and $12 \%$ grade $3 / 4$ sensory neuropathy [17].

In a randomized phase II study, 208 patients with HER2negative $\mathrm{MBC}$ were randomly assigned to first-line therapy with $260 \mathrm{mg} / \mathrm{m}^{2}$ nab-paclitaxel and $15 \mathrm{mg} / \mathrm{kg}$ bevacizumab $\mathrm{q} 3 \mathrm{w}, 260 \mathrm{mg} / \mathrm{m}^{2}$ nab-paclitaxel and $10 \mathrm{mg} / \mathrm{kg}$ bevacizumab and filgrastim q2w, or $130 \mathrm{mg} / \mathrm{m}^{2}$ nab-paclitaxel weekly and $10 \mathrm{mg} /$ $\mathrm{kg}$ bevacizumab $\mathrm{q} 2 \mathrm{w}$. For the 202 evaluable patients, there was no difference in overall response rate between the 3 regimens (arm A: 42\%, arm B: 42\%, arm C: 41\%). Median time to progression with weekly $n a b$-paclitaxel was 9.2 months and significantly longer than time to progression when $n a b$-paclitaxel was given every 3 weeks or every 2 weeks (7.7 and 6.4 months, respectively; $p=0.028)$. The study arm with biweekly nab-paclitaxel had to be closed early due to an unacceptable toxicity profile as per the protocol-specified stopping rules. The incidence of neurotoxicity $>$ grade 2 was $50 \%$ for all 3 regimens [18].

Another phase II study evaluated the combination of weekly $n a b$-paclitaxel, gemcitabine, and bevacizumab as firstline treatment of MBC. 30 patients received nab-paclitaxel $150 \mathrm{mg} / \mathrm{m}^{2}$ and gemcitabine $1,500 \mathrm{mg} / \mathrm{m}^{2}$ and bevacizumab $10 /$ $\mathrm{mg} / \mathrm{kg}$ on days $1 / 15$ of a 28 -day cycle. Overall response rate was $75.9 \%$, median progression-free survival 10.4 months, and 18-months survival rate $77.2 \% .8$ (27.6\%) patients had grade $3 / 4$ toxicity. Only 1 of these patients experienced peripheral neuropathy [19].

Recently, another phase II study reported on the combination of weekly $n a b$-paclitaxel, gemcitabine, and bevacizumab as first-line treatment in 48 evaluable patients with MBC. Patients received $n a b$-paclitaxel at $125 \mathrm{mg} / \mathrm{m}^{2}$, and gemcitabine at $1,000 \mathrm{mg} / \mathrm{m}^{2}$ on days $1 / 8$ and bevacizumab $15 \mathrm{mg} / \mathrm{kg}$ on day 1 of a 21 -day cycle. Overall response rate was $69 \%$, median progression-free survival 11.7 months, and median 1-year survival rate $84 \%$. The most common grade $3 / 4$ adverse event was neutropenia with $71 \%$. Neuropathy grade 3 occurred in $4(8 \%)$ patients [20].

The combination of weekly nab-paclitaxel and trastuzumab as first-line treatment was evaluated in a phase II study with 72 patients (50 HER2-negative and 22 HER2-positive) with locally advanced breast cancer or MBC. $N a b$-paclitaxel was administered at $125 \mathrm{mg} / \mathrm{m}^{2}$ on days $1 / 8 / 15$ of a 28 -day cycle plus concurrent trastuzumab (loading dose $4 \mathrm{mg} / \mathrm{kg}$, then $2 \mathrm{mg} / \mathrm{kg}$ weekly) for HER2-positive patients. The objective response rate was $38.1 \%$ in HER2-negative patients and $52.4 \%$ in HER2-positive patients. Median progression-free survival was 12.8 and 18.7 months and median overall survival 27.3 and 36.8 months, respectively. The majority of adverse events was grade $1 / 2$ with only 3 episodes of grade 4 toxicity (neither hematologic nor neurotoxicity). Sensory neuropathy grade 3 occurred in $6(8 \%)$ patients [21]. 
Table 2. Overview of weekly nab-paclitaxel combination schedules in metastatic breast cancer

\begin{tabular}{|c|c|c|c|c|c|c|c|}
\hline Study [ref.] & $\mathrm{n}$ & $\begin{array}{l}\text { Treatment } \\
\text { line }\end{array}$ & $n a b$-Paclitaxel & Biological agent & Cytotoxic agent & Efficacy & Toxicity \\
\hline $\begin{array}{l}\text { Somer et al. } \\
{[15]}\end{array}$ & 50 & first-line & $\begin{array}{l}125 \mathrm{mg} / \mathrm{m}^{2} \text { days } \\
1 / 8 \mathrm{q} 21 \mathrm{~d}\end{array}$ & none & $\begin{array}{l}\text { capecitabine } 825 \mathrm{mg} / \mathrm{m}^{2} \\
\text { BID days } 1-14 \mathrm{q} 21 \mathrm{~d}\end{array}$ & $\begin{array}{l}\text { ORR } 47.5 \%, \\
\text { DCR } 87 \%\end{array}$ & $\begin{array}{l}23.3 \% \text { grade } 3 / 4 \\
\text { non-hematologic } \\
\text { toxicity, no neuro- } \\
\text { toxicity grade } 3 / 4\end{array}$ \\
\hline Roy et al. [16] & 50 & first-line & $\begin{array}{l}125 \mathrm{mg} / \mathrm{m}^{2} \text { days } \\
1 / 8 \mathrm{q} 21 \mathrm{~d}\end{array}$ & none & $\begin{array}{l}\text { gemcitabine } 1,000 \mathrm{mg} / \mathrm{m}^{2} \\
\text { days } 1 / 8 \mathrm{q} 21 \mathrm{~d}\end{array}$ & $\begin{array}{l}\text { ORR } 50 \%, \\
\text { PFS } 7.9 \text { months, } \\
\text { OS at } 6 \text { months } 92 \%\end{array}$ & $\begin{array}{l}54 \% \text { grade } 3 / 4 \text { neu- } \\
\text { tropenia, } 8 \% \text { grade } \\
3 \text { neuropathy }\end{array}$ \\
\hline $\begin{array}{l}\text { Danso et al. } \\
{[17]}\end{array}$ & 45 & first-line & $\begin{array}{l}125 \mathrm{mg} / \mathrm{m}^{2} \text { days } \\
1 / 8 / 15 \mathrm{q} 28 \mathrm{~d}\end{array}$ & $\begin{array}{l}\text { bevacizumab } 10 \\
\mathrm{mg} / \mathrm{kg} \text {, days } 1 / 15 \\
\text { q28d }\end{array}$ & none & $\begin{array}{l}\text { ORR } 30 \% \text {, DCR } 52 \% \text {, } \\
\text { PFS } 9.4 \text { months }\end{array}$ & $\begin{array}{l}46 \% \text { grade } 3 / 4 \text { neu- } \\
\text { tropenia, } 12 \% \text { grade } \\
3 / 4 \text { neuropathy }\end{array}$ \\
\hline $\begin{array}{l}\text { Conlin et al. } \\
{[18]}\end{array}$ & 76 & first-line & $130 \mathrm{mg} / \mathrm{m}^{2}$ weekly & $\begin{array}{l}\text { bevacizumab } 10 \\
\mathrm{mg} / \mathrm{kg} \text { biweekly }\end{array}$ & none & $\begin{array}{l}\text { ORR } 41 \% \text {, } \\
\text { TTP } 9.2 \text { months }\end{array}$ & $\begin{array}{l}50 \% \geq \text { grade } 2 \\
\text { neurotoxicity }\end{array}$ \\
\hline Lobo et al. [19] & 30 & first-line & $\begin{array}{l}150 \mathrm{mg} / \mathrm{m}^{2} \text { days } \\
1 / 15 \mathrm{q} 28 \mathrm{~d}\end{array}$ & $\begin{array}{l}\text { bevacizumab } 10 \\
\mathrm{mg} / \mathrm{kg} \text { days } 1 / 15 \\
\mathrm{q} 28 \mathrm{~d}\end{array}$ & $\begin{array}{l}\text { gemcitabine } 1,500 \mathrm{mg} / \mathrm{m}^{2} \\
\text { days } 1 / 15 \mathrm{q} 28 \mathrm{~d}\end{array}$ & $\begin{array}{l}\text { ORR } 75.9 \%, \text { PFS } 10.4 \\
\text { months }\end{array}$ & $\begin{array}{l}27.6 \% \text { grade } 3 / 4 \text { tox- } \\
\text { icity, } 3 \% \text { grade } 3 \\
\text { neuropathy }\end{array}$ \\
\hline $\begin{array}{l}\text { Northfelt et al. } \\
{[20]}\end{array}$ & 48 & first-line & $\begin{array}{l}125 \mathrm{mg} / \mathrm{m}^{2} \text { days } \\
1 / 8 \mathrm{q} 21 \mathrm{~d}\end{array}$ & $\begin{array}{l}\text { bevacizumab } 15 \\
\mathrm{mg} / \mathrm{kg} \text { day } 1 \mathrm{q} 21 \mathrm{~d}\end{array}$ & $\begin{array}{l}\text { gemcitabine } 1,000 \mathrm{mg} / \mathrm{m}^{2} \\
\text { days } 1 / 8 \mathrm{q} 21 \mathrm{~d}\end{array}$ & $\begin{array}{l}\text { ORR } 69 \% \text {, } \\
\text { PFS } 11.7 \text { months, } \\
\text { 1-year survival } 84 \%\end{array}$ & $\begin{array}{l}71 \% \text { grade } 3 / 4 \text { neu- } \\
\text { tropenia, } 8 \% \text { grade } \\
3 \text { neuropathy }\end{array}$ \\
\hline $\begin{array}{l}\text { Mirtsching et } \\
\text { al. [21] }\end{array}$ & 22 & first-line & $\begin{array}{l}125 \mathrm{mg} / \mathrm{m}^{2} \text { days } \\
1 / 8 / 15 \mathrm{q} 28 \mathrm{~d}\end{array}$ & $\begin{array}{l}\text { trastuzumab } \\
\text { weekly }\end{array}$ & none & $\begin{array}{l}\text { ORR } 52.4 \% \text {, PFS } 18.7 \\
\text { months, OS } 36.8 \\
\text { months }\end{array}$ & $\begin{array}{l}11 \% \text { grade } 3 \text { neutro- } \\
\text { penia, } 8 \% \text { grade } 3 \\
\text { sensory neuropathy }\end{array}$ \\
\hline $\begin{array}{l}\text { Conlin et al. } \\
{[22]}\end{array}$ & 32 & first-line & $\begin{array}{l}100 \mathrm{mg} / \mathrm{m}^{2} \text { days } \\
1 / 8 / 15 \mathrm{q} 28 \mathrm{~d}\end{array}$ & $\begin{array}{l}\text { trastuzumab } \\
\text { weekly }\end{array}$ & $\begin{array}{l}\text { carboplatin } \mathrm{AUC}=2 \text { days } \\
1 / 8 / 15 \text { or } \mathrm{AUC}=6 \text {, day } 1 \\
\mathrm{q} 28 \mathrm{~d}\end{array}$ & $\begin{array}{l}\text { ORR } 62.5 \%, \\
\text { DCR } 81 \%, \\
\text { PFS } 16.6 \text { months }\end{array}$ & $\begin{array}{l}9 \% \text { grade } 4 \text { neutro- } \\
\text { penia, } 3 \% \text { grade } 3 \\
\text { peripheral } \\
\text { neuropathy }\end{array}$ \\
\hline
\end{tabular}

ORR = Overall response rate; $\mathrm{DCR}=$ disease control rate; $\mathrm{PFS}=$ progression-free survival; $\mathrm{OS}$ = overall survival; $\mathrm{AUC}=$ area under the curve .

A multicenter phase II study in 33 patients with HER2positive MBC evaluated the efficacy and safety of weekly $n a b$-paclitaxel in combination with carboplatin and weekly trastuzumab as first-line therapy. Patients received $100 \mathrm{mg} / \mathrm{m}^{2}$ $n a b$-paclitaxel on days $1 / 8 / 15$ in combination with carboplatin at area under the curve (AUC) $=2$ on days $1 / 8 / 15$ (in the first set of 13 patients) or at $\mathrm{AUC}=6$ on day 1 (in the latter set of 19 patients) of a 28-day cycle. Trastuzumab was administered at $2 \mathrm{mg} / \mathrm{kg}$ weekly after a loading dose of $4 \mathrm{mg} / \mathrm{kg}$. The overall response rate was $62.5 \%$, clinical benefit rate $81 \%$, and median progression-free survival 16.6 months. Hematologic toxicities were the only grade 4 toxicities reported with $9 \%$ grade 4 neutropenia and 1 case of febrile neutropenia. The frequency of peripheral neuropathy was $13 \%$ for grade 2 and $3 \%$ for grade 3 toxicity [22]. A short overview of the trials with weekly single agent $n a b$-paclitaxel in combination in $\mathrm{MBC}$ described in detail above is given in table 2 .

Feasibility of weekly paclitaxel in combination with carboplatin and trastuzumab or bevacizumab was demonstrated in a cohort of 106 patients with large and inflammatory breast cancer resistant or sensitive to the combination of doxorubicin and cyclophosphamide (AC) [23]. Patients were treated with growth factor-supported dose dense AC for 2 cycles if resistant or 4 cycles if sensitive to AC. Patients then received 9-12 doses of weekly conventional paclitaxel or albuminbound paclitaxel in combination with carboplatin plus bevacizumab in the case of HER2-negative tumors or weekly trastu- zumab in the case of HER2-positive disease. This treatment resulted in pathological complete response (pCR) in 38 of 84 assessable tumors with pCR being independent of ACresistance and sensitivity. More detailed information on the feasibility and toxicity of weekly nab-paclitaxel in combination with trastuzumab can also be derived from a phase II neoadjuvant study in 66 patients with locally advanced breast cancer. Nab-paclitaxel was administered at a dose of $100 \mathrm{mg} /$ $\mathrm{m}^{2}$ weekly for 12 weeks and then followed by chemotherapy with 4 cycles of FEC (5-fluorouracil $500 \mathrm{mg} / \mathrm{m}^{2}$, epirubicin 100 $\mathrm{mg} / \mathrm{m}^{2}$ or $75 \mathrm{mg} / \mathrm{m}^{2}$ in the case of HER2-positivity, cyclophosphamide $500 \mathrm{mg} / \mathrm{m}^{2}$ on day 1 of a 21-day cycle). HER2-positive patients received trastuzumab $(4 \mathrm{mg} / \mathrm{kg}$ loading dose and $2 \mathrm{mg} / \mathrm{kg}$ weekly subsequently) starting with the first dose of $n a b$-paclitaxel. pCR was seen in $29 \%$ of all patients, and in $58 \%$ of the HER2-positive, $17 \%$ of the HER2-negative and $28 \%$ of the triple-negative subgroup. Estimated progressionfree survival at 2 years was $81 \%$ and median overall survival at 2 years $95 \%$. Toxicity was reported for all patients regardless of HER2-status. No grade 4 toxicity was reported during $n a b$-paclitaxel therapy. For treatment with $n a b$-paclitaxel, the frequency of neutropenia grade 3 was $3 \%$; febrile neutropenia was recorded for $2 \%$ of cases. The incidence of neuropathy grade 3 was $5 \%$, and $11 \%$ for neuropathy grade 2 . The authors state that co-administration of trastuzumab did not appear to alter the toxicity profile of $n a b$-paclitaxel [24]. 


\section{Discussion}

$N a b$-paclitaxel has been registered as monotherapy with a recommended dose of $260 \mathrm{mg} / \mathrm{m}^{2} \mathrm{q} 3 \mathrm{w}$ for the treatment of patients with $\mathrm{MBC}$, who have failed a first-line treatment of metastatic disease and for whom a standard anthracycline treatment is not indicated. However, data from clinical studies on the use of $n a b$-paclitaxel in first-line and in weekly schedules as a single agent and in combination with biologicals, other cytotoxic agents, or both offer the basis for a more flexible scheduling and dosing dependent on the specific situation of the individual patient.

Data of the pivotal clinical study demonstrated that nabpaclitaxel at $260 \mathrm{mg} / \mathrm{m}^{2} \mathrm{q} 3 \mathrm{w}$ provides a superior overall response rate, time to progression and progression-free survival, and a better safety profile compared to solvent-based paclitaxel. Of note, the study was positive regarding its primary endpoint for all patients and subgroups, i.e. also for the approximately $40 \%$ of first-line patients [9]. The exceptional survival benefit in second-line chemotherapy is of particular interest in light of the evidence of other standards for secondline chemotherapy such as capecitabine, vinorelbine, and pegylated doxorubicin.

The weekly administration of single agent nab-paclitaxel has shown considerable efficacy as first-line treatment of MBC with an impressive median overall survival of 33.8 months for the $150 \mathrm{mg} / \mathrm{m}^{2}$ dose [11], while overall survival was 26.6 months for first-line therapy with docetaxel $100 \mathrm{mg} / \mathrm{m}^{2}$ $\mathrm{q} 3 \mathrm{w}$ and 27.7 months for first-line therapy with $n a b$-paclitaxel $300 \mathrm{mg} / \mathrm{m}^{2} \mathrm{q} 3 \mathrm{w}$. In the independent radiologist assessment, both the $150 \mathrm{mg} / \mathrm{m}^{2}$ and the $100 \mathrm{mg} / \mathrm{m}^{2}$ weekly schedule of $n a b$-paclitaxel revealed a superior progression-free survival as compared to docetaxel $100 \mathrm{mg} / \mathrm{m}^{2} \mathrm{q} 3 \mathrm{w}[10,11]$. In heavily pre- treated taxane-refractory patients, weekly nab-paclitaxel exerted a good efficacy profile at a dose of $125 \mathrm{mg} / \mathrm{m}^{2}$ and at 100 $\mathrm{mg} / \mathrm{m}^{2}$ [12]. Weekly nab-paclitaxel at $125 \mathrm{mg} / \mathrm{m}^{2}$ could be safely combined with either bevacizumab or trastuzumab. Both combinations showed considerable activity as first-line regimens [17, 18, 21]. Nab-paclitaxel combinations at a dose of $125 \mathrm{mg} / \mathrm{m}^{2}$ with capecitabine and gemcitabine were feasible, safe and active $[15,16]$. Triple combinations of a biological and 2 cytotoxic agents as first-line treatment were tested with the $125 \mathrm{mg} / \mathrm{m}^{2}$ dose plus gemcitabine and the $100 \mathrm{mg} / \mathrm{m}^{2}$ dose with carboplatin, and proved active and manageable [19, 20, 22].

For most physicians involved in the care of patients with pretreated MBC, a weekly schedule of nab-paclitaxel might be the preferred choice because it allows them to monitor treatment closely and to react promptly to the onset of side effects such as neuropathy. The challenge to pick the adequate dose for the individual patient will depend on the therapeutic ratio of the respective regimen. For nab-paclitaxel this is linked to the probability of sensory neuropathy. Grade 4 sensory neuropathy did not occur with any of the studied nabpaclitaxel regimens. The incidence of grade 3 neuropathy ranges from $10 \%$ for the 3 -weekly schedule up to $14 \%$ for the weekly $150 \mathrm{mg} / \mathrm{m}^{2}, 6-12 \%$ for the weekly $125 \mathrm{mg} / \mathrm{m}^{2}$, and $0-8 \%$ for the weekly $100 \mathrm{mg} / \mathrm{m}^{2}$ regimen in first line. In heavily taxane-pretreated patients, the incidence was $19 \%$ for the $125 \mathrm{mg} / \mathrm{m}^{2}$ and $8 \%$ for the $100 \mathrm{mg} / \mathrm{m}^{2}$ weekly schedule. Sensory neuropathy occurs relatively late in the course of treatment. Gradishar et al. [11] reported the time to onset of grade 3 neuropathy to be 189 days for the $100 \mathrm{mg} / \mathrm{m}^{2} \mathrm{q} 1 \mathrm{w}, 162$ days for the $150 \mathrm{mg} / \mathrm{m}^{2} \mathrm{q} 1 \mathrm{w}$, and 151 days for the $300 \mathrm{mg} / \mathrm{m}^{2} \mathrm{q} 3 \mathrm{w}$ dose. They also reported that neuropathy could be adequately managed with interruptions and dose reductions. Time to im-

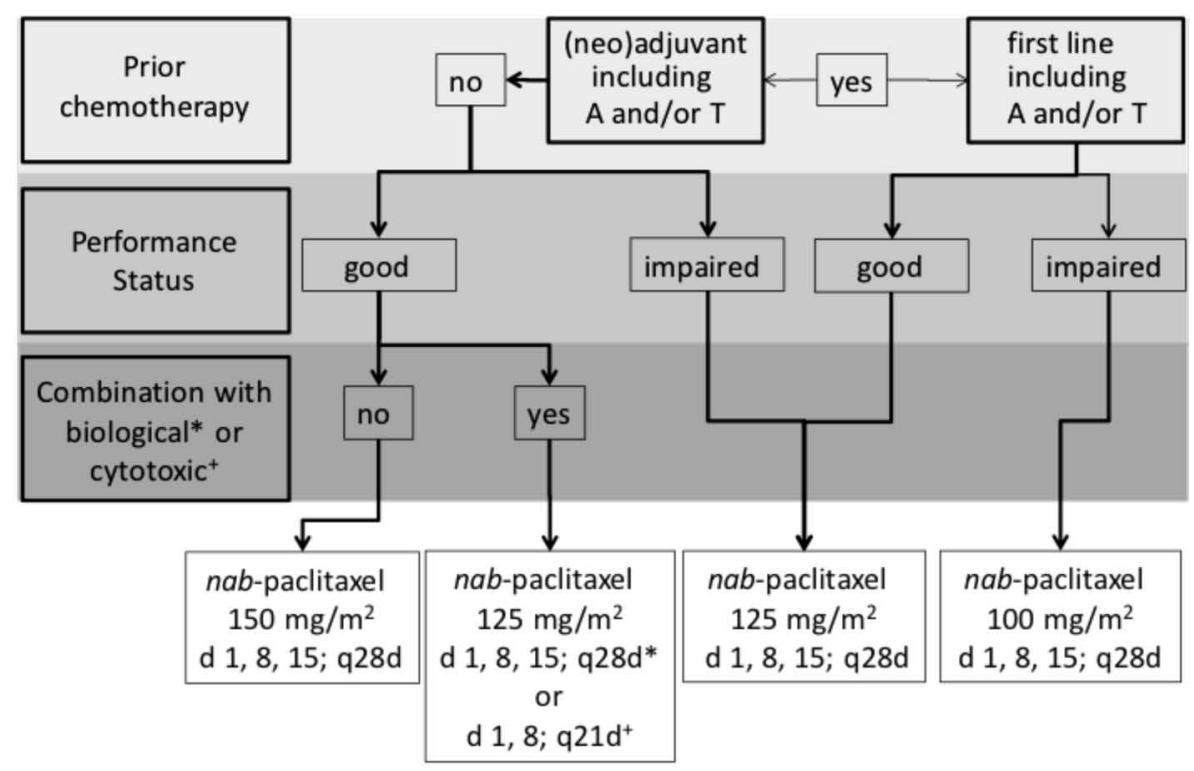

142

Breast Care 2012;7:137-143
Fig. 1. Algorithm for use of weekly nab-paclitaxel in metastatic breast cancer (*bevacizumab $10 \mathrm{mg} / \mathrm{kg}$ days $1 / 15$, trastuzumab $4 \mathrm{mg}$ loading dose and $2 \mathrm{mg} / \mathrm{kg}$ weekly; + data with capecitabine and gemcitabine from phase II trials). 
provement to grade 2 or less was consistent for the 3-weekly and the weekly regimens and occurred after only 22, 20 and 22 days, respectively.

In summary, Nab-paclitaxel can be used as a 3-weekly schedule, but it is also justifiable to administer it in various weekly schedules in metastatic MBC. Moreover, combinability with biological and cytotoxic agents has been primarily evaluated with weekly schedules. Sensory neuropathy occurs late in the course of treatment, can be managed by interruptions and dose reductions and improves or resolves rapidly. In some cases, logistic considerations may determine the choice of schedule, e.g. a long distance to the treating clinic may trigger the decision for a 3-weekly administration. If a physician decides to use $n a b$-paclitaxel to treat a patient with MBC and would prefer a weekly regimen, the algorithm in figure 1 may be a useful guidance regarding schedule and dose based on the evidence discussed. Overall, in first and further lines of therapy of MBC, nab-paclitaxel proved to be an effective therapy. It is also a valid chemotherapy option for patients pretreated with both anthracycline and taxane. $\mathrm{Nab}$-paclitaxel offers flexible scheduling. The choice of the appropriate $n a b$ - paclitaxel regimen is guided by prior cytotoxic therapy for metastatic disease, by the patient's condition, or by the combination with a biological or a second cytotoxic agent. In addition, the growing evidence regarding efficacy and safety of combining nab-paclitaxel with antibodies opens new options in the systemic treatment of MBC. Nab-paclitaxel is also expected to have only limited cross-resistance to solvent-based taxanes and might therefore be indicated in a setting of relapse occurring within $<12$ months after a taxane-containing (neo)-adjuvant therapy. This will be evaluated in the ongoing multicenter single arm phase II study TIFFANY in which patients with $\mathrm{MBC}$ failing a (neo)-adjuvant treatment with a solvent-based taxane receive first-line weekly nab-paclitaxel.

\section{Disclosure Statement}

Support for the advisory board and development of the manuscript was provided by an unrestricted grant from Celgene Deutschland GmbH. The authors received an honorarium for attending the meeting but not for writing the manuscript. The authors are solely responsible for the content of the manuscript with no restrictions set by the sponsor.

\section{References}

1 AGO: Guidelines Breast, version 2012.1D; www.ago-online.de.

2 Sparano JA, Wang M, Martino S, et al.: Weekly paclitaxel in the adjuvant treatment of breast cancer. N Engl J Med 2008;358:1663-1671.

$\checkmark 3$ Seidman AD, Berry D, Cirrincione C, et al.: Randomized phase II trial of weekly compared with every-3-weeks paclitaxel for metastatic breast cancer, with trastuzumab for all HER-2 overexpressors and random assignment to trastuzumab or not in HER-2 nonoverexpressors: final results of Cancer and Leukemia Group B protocol 9840. J Clin Oncol 2008;26:1642-1649.

4 Authier N, Gillet JP, Fialip J, et al.: Assessment of neurotoxicity following repeated cremophor/ethanol injections in rats. Neurotox Res 2001;3:563564.

$>5$ Ten Tije AJ, Verweij J, Loos WJ, Sparreboom A: Pharmacological effects of formulation vehicles: implications for cancer chemotherapy. Clin Pharmacokinet 2003;42:665-668.

6 Sparreboom A, van Zuylen L, Brouwer E, et al.: Cremophor EL-mediated alteration of paclitaxel distribution in human blood: clinical pharmacokinetic implications. Cancer Res 1999;59:1454-1457.

7 Hamad I, Moghimi SM, et al.: Critical issues in sitespecific targeting of solid tumours: the carrier, the tumour barriers and the bioavailable drug. Expert Opin Drug Deli 2008;5:205-219.

8 Minshall RD, Tiruppathi C, Vogel SM, et al.: Vesicle formation and trafficking in endothelial cells and regulation of endothelial barrier function Histochem Cell Biol 2002;117:105-112.

$\checkmark 9$ Gradishar W, Tjulandin S, Davidson N, et al.: Phase III trial of nanoparticle albumin-bound paclitaxel compared with polyethylated castor oil-based paclitaxel in women with breast cancer. J Clin Oncol 2005;23:7794-7803.
10 Gradishar W, Krasnojon D, Cheporov S, et al.: Significantly longer progression-free survival with nab-paclitaxel compared with docetaxel as first line therapy for metastatic breast cancer. J Clin Oncol 2009;27:3611-3619.

11 Gradishar WJ, Krasnojon D, Cheporov S, et al.: Albumin-bound paclitaxel (ab-pac) versus docetaxel for first-line treatment of metastatic breast cancer (MBC): final overall survival (OS) analysis of a randomized phase II trial. ASCO Breast Cancer Symposium 2011;abstr 275.

12 Blum J, Savin M, Edelman G, et al.: Phase II study of weekly albumin-bound paclitaxel for patients with metastatic breast cancer heavily pretreated with taxanes. Clin Breast Canc 2007;7:850-856.

13 Abraxane ${ }^{\circledR}$ prescribing information.

14 Brezden C, Cantin G, Younus J, et al.: An openlabel, phase II study of weekly nab-paclitaxel as first-line therapy for patients with metastatic breast cancer: safety update. J Clin Oncol 2010;28 (suppl 159):abstr 1127.

15 Somer BD, Schwartzberg LS, Arena F, Epperson A, Fu D, Fortner BV: Phase II trial of nab-paclitaxel (nanoparticle albumin-bound paclitaxel $(\mathrm{ABX})$ ) + capecitabine (XEL) in first-line treatment of metastatic breast cancer (MBC). ASCO Ann Meet Proc Part I, J Clin Oncol 2007;25:1053.

16 Roy V, LaPlant BR, Gross GG, et al.: Phase II trial of weekly nab (nanoparticle albumin-bound)-paclitaxel (nab-paclitaxel) (Abraxane ${ }^{\circledR}$ ) in combination with gemcitabine in patients with metastatic breast cancer (N0531). Ann Oncol 2009;20:449-453.

17 Danso M, Blum J, Robert N, et al.: Phase II of weekly nab-paclitaxel in combination with bevacizumab as first line treatment in metastatic breast cancer. J Clin Oncol 2008;26(suppl):abstr 1075.
18 Conlin A, Hudis C, Bach A, et al.: Randomized phase II trial of nanoparticle albumin-bound paclitaxel in three dosing schedules with bevacizumab as first-line therapy for HER2-negative metastatic breast cancer (MBC). J Clin Oncol 2009;27 (suppl 15):abstr 1006.

19 Lobo C, Lopes G, Baez O, et al.: Final results of a phase II study of nab-paclitaxel, bevacizumab and gemcitabine as first-line therapy for patients with HER2-negative metastatic breast cancer. Breast Cancer Res Treat 2010;123:427-435.

20 Northfelt DW, Dueck AC, Flynn TP, et al.: Phase II trial combining nab-paclitaxel (NP), gemcitabine $(\mathrm{g})$, and bevacizumab (B) in patients with metastatic breast cancer (MBC): NCCTG N0735. J Clin Oncol 2011;29(suppl):abstr 1126.

21 Mirtsching B, Cosgriff T, Harker G, et al.: A phase II study of weekly nanoparticle albumin-bound paclitaxel with or without trastuzumab in metastatic breast cancer. Clin Breast Canc 2011;11:121-128.

22 Conlin A, Seidman A, Bach A, et al.: Randomized phase II trial of nanoparticle albumin-bound paclitaxel with carboplatin and trastuzumab as first line therapy for women with HER2-overexpressing metastatic breast cancer. Clin Breast Cancer 2010;10:281-287.

23 Mehta RS, Schubbert T, Kong K, et al.: Pathologic complete response (pCR) following weekly (wkly) paclitaxel (cremophor or albumin-bound) and carboplatin $(\mathrm{TC}) \pm$ trastuzumab $(\mathrm{H}), \pm$ bevacizumab (B) in patients (pts) with doxorubicin/ cyclophosphamide-resistant (AC-Res) and ACsensitive (AC-S) large and inflammatory breast cancer. ASCO Ann Meet Proc Part I, J Clin Oncol 2007;25(suppl):591.

24 Roubidoux A, Buzdar AU, Quinaux E, et al.: A phase II neoadjuvant trial of sequential nanoparticle albumin-bound paclitaxel followed by 5-fluorouracil/epirubicin/cyclophosphamide in locally advanced breast cancer. Clin Breast Canc 2010;10:81-86. 